\title{
Managing the People: Art Programs in
}

\section{the American Depression}

\section{By}

\section{Dr. Lisanne Gibson ${ }^{1}$}

\footnotetext{
${ }^{1}$ Thanks to the Privatisation of Culture Project and the American Studies Program of New York University for the provision of a Rockefeller Postdoctoral Fellowship which provided the time and resources to research this topic. The Project also provided opportunities for the discussion of the history of cultural programs amongst a variety academics and arts administrators; I found participation in this debate both stimulating and useful.
} 


\section{Introduction}

It has become increasingly familiar to explain the contemporary arrangements for the management of culture in terms of culture's 'privatization'. This characterisation describes a trend identifiable across all those governmental sectors-health, education, and social security-established (in their nationalised form) as part of the post-world war two welfare state. As there has been a (relative) withdrawal of government from these sectors, so too has the notion that government has a role to play in relation to the subvention of culture increasingly come into question. This shift in governmentality produces a range of problems, for instance, access to diverse cultural resources, cultural pluralism, funding for non-profitable 'research and development' in the cultural sector; I have discussed these problems elsewhere. $^{2}$ It is not the function of this paper to revisit or discuss further the issues at stake in this shift in governmentality which has produced a new range of cultural technologies for the management of the population. Rather, via the discussion of a selection of art programs from the 1930s I want to offer a particular theoretical framework for the analysis of conjunctions of culture and government.

It is possible to provide a distinctive perspective on the history of culture and government by arguing that the relations between culture and government are best defined by the ways in which different strategies for the management of populations have been organised and deployed. These relations have been various but above all can be understood by the ways in which government has strategically used art to act on 'the social'. This analysis seeks to describe the intersection of the different organising principles which inform the conjunctions of art, citizenship and government. This description will emphasise the complex and contradictory nature of rationales for arts administration. In other words, I find no single defining logic to explain the particular forms of art's governmentalisation in the thirties.

\footnotetext{
${ }^{2}$ I have discussed this shift as it has occurred in Australia in ‘The Arts as Industry’ 1999.
} 
I want to establish immediately that my conception of government is not limited to organisations or mechanisms attached to the state. Rather, analysis of the relations between art and citizenship is informed by an understanding of governmental power drawn from a particular reading of Michel Foucault's concept of 'governmentality' (Foucault, 1991). In brief there are three aspects of this concept which are useful for this inquiry. The first is the notion that not all forms of political power have their origins in the state; rather, government refers to the activities of all institutions concerned with the regulation and management of populations. Second, is the precept that government is not unified in its function. Governmental rationales and technologies are distinctive and have distinct histories. Third, is the notion that the object of government is population, and that to this object is brought an amalgam of techniques with particular objectives which are practical. In relation to this, Foucault suggests that government is intrinsically involved with moulding both public and private behaviour, or, to put it another way, government is concerned with the 'conduct of conduct'.

The period of the 1930s and 1940s is especially significant for the ways in which arts funding came to be institutionalised in the post-war Anglophone world. During the 1930s and 1940s the arts were administered by an increasingly diverse range of organisations. This had two direct outcomes. The first outcome was that there was an increased political expectation that it was a responsibility of the state to fund and administer art. This meant that in a time of dire economic and political circumstance, due first to the Depression and then to WWII, there were multiple initiatives for administering the arts with the aim of extending access and participation. In the second place, linked to this shift in arts management, there was a shift in the way 'the people' were constructed in relation to art. Far from art being thought of as the property of the few or the elite, the definitive art programs of the 1930s and early 1940s were titled 'Art for the People' and proudly proclaimed that art was the property of 'Everyman'. Both of 
these discursive shifts were the outcome of much longer histories. Specifically, they can be seen in relation to the more general movement towards different strategies for the management of 'the social', which can be traced from the early nineteenth century in, for example, museum policy.

The 1930s and 1940s are significant for the ways in which cultural policy sought to act on the citizen from a distance. These strategies hoped to produce and encourage citizens capable of self-regulation in a way that would ensure their active and productive contribution to the nation. Thus, artists in America were encouraged to paint 'American', British culture became a symbol of 'what we are fighting for', and, in the latter half of the 1940s, cultural programs were a significant part of the Australian reconstruction. In each of these instances the promise of cultural access was part of the promise of a new reconstructed nation. Above all these programs can be understood as being characterised by a particular governmental rationality. This 'welfarist' rationality constructed the citizenry as consisting of free individuals responsible for their own self-management. The cultural technologies of the 1930s and 1940s constructed the citizenry as freely participating members of a democracy to be protected and saved from the fascist threat. Characteristic of the 1930s was a contradictory concern with the 'government culture' of fascism on the one hand and an increasingly dominant perception that subvention of cultural production was a state responsibility. Thus, art programs managed by the state were characteristically part of the governmental tendencies of social-welfarism. As a result of the competing logics characteristic of the welfarist governmental rationality, cultural and social technologies of the 1930s and 1940s sought to manage the citizen from 'arm's length'. Art programs were one of the ways in which the citizenry was educated to manage itself in relation to a certain set of desirable norms. During the 1930s in America these norms were set in relation to the construction of a free citizen who had the capacities to participate in the reconstructed democratic New Deal America. We will have an opportunity to interrogate the terms of these constructions later, for now I want to state 
that there is no single logic through which we can understand this formation of culture and government. To describe the relations between art, citizenship, and government as a formation is to recognise the characteristic and defining features of this conjunction but it is also to recognise the nature of this formation as constituting a field in which a number of changing elements are in constant competition.

\section{Federal Art Project}

As the most well known of the 1930s art projects and as the only art project which was specifically a creation of the New Deal, it is fitting to begin our discussion with the Federal Art Project (FAP). In 1935 the Emergency Relief Appropriation Act was passed by Congress, this Act gave government broad powers to centralise the administration of and provide funds for the problem of unemployment relief. To administer this problem the Federal Works Agency was inaugurated in 1935 and was made up of the Works Progress Administration (WPA) and other administration units. Within the WPA in the Division of Professional and Service Projects a section was established titled Federal Project Number One. Federal One, as it was called, was made up of the FAP, the Federal Theatre Project, the Federal Music Project, the Federal Writers Project, and the Historical Records Survey.

There are two primary reasons why government organised and funded the large art projects of the New Deal. In the first instance, the FAP received appropriations from Congress primarily as a work relief project designed to create employment for unemployed artists. We must underscore the novelty of this idea involving as it did 'a radical revision of the traditional conception, for it implied that it was normal for artists to be hired for fees or wages...' (Rosenburg, 1975, p. 197). Nevertheless, at its peak the FAP employed more than 5,000 artists. The second primary reason for government attention to the arts in the midst of the Depression was because the FAP was also understood as having a wider social function. In particular art created by FAP programs was characterised as 'art for the people', this was art that spoke 
to and depicted the life of the 'people' understood as citizens participating in the reconstruction of the nation. The art projects operated as a mechanism through which the New Deal citizen was to be educated and equipped with a variety of capacities. For instance, the citizen was to be educated as a discerning consumer. This citizen-consumer would be equipped not only with the attributes to participate in the workings of the new reconstructed American nation through the exercise of her or his social and political responsibilities but also through the thrifty expenditure of her or his capital and the sensible expenditure of her or his leisure time. Director of the FAP, Holger Cahill, explained how the FAP might contribute to the education of good consumption practices when he wrote that 'We are not particularly interested in developing what is known as art appreciation. We are interested in raising a generation sensitive to their visual environment and capable of helping to improve it' (in McKinzie 1973, p. 130). Thus, the FAP was typical of the New Deal in that it operated not only according to the immediate aim of aid to artists but also with a greater social goal in mind.

Cahill made a broader statement of the FAP's various social aims in a FAP operating manual written in 1935:

The plan of the FAP provides for the employment of artists in varied enterprises. Through employment of creative artists it is hoped, through art teaching and recreational activities to create a broader national art consciousness and work out constructive ways of using leisure time, through services in applied art to aid various campaigns of social value. The aim of the project will be to work toward an integration of the arts with the daily life of the community, and an integration of the fine arts and practical arts. (in O’Connor 1969, p. 28) 
There are three linked aims in this statement: art programs would encourage a more artistically aware population who would expend their leisure time in constructive ways; applied art would be utilised in campaigns advocating particular social values (such as, murals in hospitals, schools, public art in government housing spaces and so forth); and through these types of programs, the FAP would engender a bonding of applied and fine art. These aims would result in the production and consumption of better design, and more widely accessible (both physically and intellectually) cultural production; in a phrase the Project would produce and advocate 'useful culture'. The FAP, far from being simply a work relief programme for artists, was primarily understood as a programme which could provide an education in the civic capacities which would be required under the more collectively aligned New Deal state.

The community art centre programme most clearly reflected the FAP's more instrumental goals in relation to the education of citizenship. ${ }^{3}$ While the community art centre was part of a relatively small section of the FAP the rationales framing the programme are illustrative of the larger project. The community art centres, along with the FAP mural program, were the public faces of the project. According to historian Page Smith, by 1940 an estimated eight million people had attended the one hundred art centres established by the FAP (1987, p. 810).

\footnotetext{
${ }^{3}$ However, we must bear in mind that the educational services section, of which the community art centres were a part, made up only $17 \%$ of the FAP. The project consisted of the following sections: 48\% fine art (murals, sculpture, easel painting, graphic arts), 29\% practical and applied arts (posters, photography, Index of American Design, arts and craft, models), 17\% educational services (federal art galleries, community art centres, art teaching, research and information), $6 \%$ technical and supervisory (Berman 1977, p.xvii-viii). McDonald states that by 1939 the education section had grown to $25 \%$ of the project (1969, p. 422-23).
} 
The community centres were based on two main aims. The first was to provide democratic access to culture, thus, Assistant Director of the FAP, Thomas Parker, said that the centres were devoted 'to returning art to the people, to all the people' (in McKinzie 1973, p. 141). In the second place the centres were a site for the management and reconstruction of citizens who for various reasons were disaffected, disconnected and/or defined as dysfunctional. In this sense then art was used as social therapy. Irving Marantz, an FAP artist teacher, put the utility of art in this way when he commented that art was 'a great therapy' which could turn juveniles (and by implication other misfits) 'into useful social beings' (1973, p. 198). Thus, the Community Art Centre Programme targeted areas which were considered 'culturally needy'- rural and desert areas, deprived urban communities and new housing developments. A project statement put the importance of the Community Art Centres in this way the draining of America's best talent from the native soil of the small town to the strange pavements of the big city, has inundated certain sections of America and left others high and dry as potential cultural wastelands. It seems essential for the best interests of American cultural life that this process now be reversed. The provinces of America may yet become as important to the cultural life of America as the provinces of France and Germany are to their respective cultures. (in White 1987, p. 2)

Thus, areas and communities defined as peripheral to the nation were reconstructed in Project discourse as essential to the cultural development of the national whole.

Perhaps one of the most distinctive aspects of the community art centres and the aspect that most distinguishes the form of cultural consumption promoted in the 1930s is the emphasis on participation in the production process rather than the finished product. Across the limited literature available on the community art centres there are assertions from both project bureaucrats and artist teachers of the 
necessity of active participation by people attending the art centres. The artists' statement presented at the opening of Chicago's South Side Community Art Centre is illustrative in this respect.

As teachers, some of us were able to unearth, encourage and develop dormant talents of many. As artists ourselves, creatively, we were able to experiment and work in many techniques and processes which were denied to us before because we would not afford to pay to go to art schools or because we were discriminated against as Negroes. We feel that with this art centre, a worthwhile contribution is being made to all the peoples of the community. This art centre is an opportunity for self-expression and development for all people. We truly feel that art belongs to all of the people and should be enjoyed by all. (in Burroughs 1987, p. 138)

This statement is not singular, there are similar statements in relation to the Harlem, LeMoyne and Jacksonville Negro Community Art Centres for instance. These statements characteristically attribute the Community Art Centre programme and the FAP with providing both the space and opportunity for black artists to bring their work to black communities. What is striking about these statements is the way in which art centres are seen as addressing an endemic discrimination against black artists at the same time as providing a space for cultural production which is for 'all the people', not just the black communities in which the centres were situated. ${ }^{4}$ In this way in Community Art Centre discourse the black artist figured as an artist-citizen who could contribute directly to the reconstruction of the nation by encouraging the development of a particular kind of institutionally based participatory cultural process. The facilitation of this participatory cultural process by the art centre and the artist-citizen would retrieve communities from their occupation of the periphery to participate in the reconstruction

\footnotetext{
${ }^{4}$ Most community art centres either closed or became devoted to war efforts after the United State's entry into WWII.
} 
of a New Deal America. Despite the obvious point that black communities were not able to participate politically in the reconstruction of the nation, community art centre discourse emphasised the participatory and democratic nature of cultural production and consumption. Thus, art centres in Negro communities were constructed as both community based and as contributing to a holistic understanding of a reconstructed American culture characterised above all by a participatory democracy. In this way community art centres placed in communities which were seen as peripheral were designed to reconnect such communities with the national whole.

These art centres were popular in their appeal and quote impressive attendance figures, for instance, the Harlem Community Art Centre had over 70,000 attendees in its first sixteenth months (Bennett 1973, p. 214), the Jacksonville, Florida Community Art Centre had 40,000 attendees in the three years of its operation (Sutton 1973, p.216). It is not persuasive to dismiss the popularity of such centres as 'false consciousness' or to describe the workings of the centres and the New Deal in general in terms of a state based cultural hegemony ${ }^{5}$. Such explanations do little to explain a variety of points relating to the operation of the programme as a separate New Deal art programme or the specific workings of individual centres. For instance, the ratio of art centres continued to increase after the withdrawal of federal administration due to the shift against the New Deal from 1937 onwards. Or how do we account for the fate of those centres, for instance the Harlem Community Art Centre, which were closed as a result of investigations by the House of Un-American Activities Committee. ${ }^{6}$ Analyses attributing a single state based ideological logic to the working of cultural programs cannot account for the specific and concrete workings and effects of such programs. This is not to deny that there are particular power

\footnotetext{
${ }^{5}$ See for instance Jonathan Harris’s (1995) otherwise interesting history of the FAP.

${ }^{6}$ Thanks to Joan Saab for this information.
} 
effects but it is to recognise that such effects, intended or otherwise, are always the result of a process of negotiation between competing interests and discourses in the sites of their application.

\section{Section of Painting and Sculpture}

The other main art project of the 1930s was the Section of Painting and Sculpture established in 1934 and in operation until 1943. The Section, which received its funds directly from Treasury, commissioned work for the embellishment of Federal buildings. The Section was not a work relief project, selection for commissions was on the basis of quality and the requirements were quite specific. The members of the Section advisory committee were proponents of realist art depicting the 'American scene' and were antagonistic to European modernist art. 'Painting Section', as Thomas Hart Benton disparagingly described it, involved a realist style which depicted 'the people' as heroic in their daily activities. ${ }^{7}$ Thus Section art presented images of 'the people' practising civic responsibility in their work and social occupations.

While it was important that Section artists celebrated the 'American Way of Life' in their commissioned works, this art also had to be representative of the best of American talent. The primary goal of the Section, as stated in its first Bulletin in 1935, was to 'secure suitable art of the best quality for the embellishment of public buildings' (in O'Connor 1969, p. 21). Edward Bruce, the Director of the Section, put the aim this way:

\footnotetext{
${ }^{7}$ In a similar sense history painting was the favoured style of the early days of the French Revolution, involving depiction of the classical virtues, it was argued history painting could best communicate and glorify a particular range of civic virtues. (see Crow, 1985)
} 
Our objective should be to enrich the lives of all our people by making things of the spirit, the creation of beauty part of their daily lives, by giving them new hopes and sources of interest to fill their leisure, by eradicating the mere utility, and by fostering all the simple pleasures of life which are not important in terms of dollars spent but are immensely important in terms of a higher standard of living. (in Park and Markowitz 1992, p. 132)

The envisaged outcome of the Section art project was not only the education of the 'everyman' in the civic virtues but also the training of 'good' citizenship was indivisible from a training in 'good' consumption. This emphasis had two main configurations; first, there was an interest in an education for the proper use of leisure time; second, there was an emphasis on training the people to recognise, produce and purchase good quality design.

This insertion of quality art into the daily lives of the people was to be achieved by the nation-wide distribution of art in small federal buildings, such as post offices. During the nine years of the Section's existence it commissioned murals and sculpture for federal buildings and eleven hundred new post offices across America (Park and Markowitz 1992, p. 136-7). A Section Bulletin described the post office as 'the one concrete link between every community of individuals and the Federal government' that functioned 'importantly in the human structure of the community' (in Park and Markowitz 1984, p. 8). The distribution of art in this way was instrumental in terms of the establishment of a visual connection between art, government, and the people. The murals in small federal buildings interpreted this relation and depicted it as a celebration of nation and citizenship. These national representations were at the same time local and regional as the Section required that artists work extensively with the local community. In this way the Section could claim that the commissioning process and its outcome was one of collaboration between community, artist and government. Thus Section art articulated both 
the particular identity of the community and at the same time connected this specific identity into the greater whole of the reconstructed America.

Karal Ann Marling's history of post-office murals discusses the extent to which the collaborative process advocated by the Section can be taken as reflecting the reality of the commissioning process (1982). Marling finds that the commissioning process was different in each town depending on the effort to which the artist went in seeking community feedback and the extent to which the community wanted to be involved. However, it is clear from Marling's study that while Section rhetoric encouraged community consultation, the administrative organisation of the Section did not facilitate such consultation. Nevertheless, it would be an exaggeration to understand the workings of the Section simply as involving the installation of works which the community passively accepted. Both Marling and Park and Markowitz, in another study of post-office murals, discuss various instances where works which the community did not like, were either not installed or quickly taken down (Marling 1982, p.14 and Park and Markowitz 1984, p. 8). The process for commissioning, production and installation of such works was based on the precept of community consultation. Analysis of the concrete circumstances of the commissioning and installation processes of the Section is enlightening in relation to the negotiated nature of the outcomes of cultural programs under the New Deal. ${ }^{8}$

\section{The America Artist's Congress}

The connection between art, government and the people was articulated distinctively by the Artist's Union of America and the American Artist's Congress. Both of these organisations, while organised

\footnotetext{
${ }^{8}$ See for a history of the Section Park and Markowitz 1984 and for discussion of the reception of particular murals commissioned by the Section Beckham 1989 and Marling 1982.
} 
around different primary aims acted to professionalise the construction of the artist. Both the Union and the Congress presented the figure of the artist as a professional 'cultural worker' whose work was integrally tied to the achievement and maintenance of a popular democracy. In this way the Union and the Congress claimed that funding of the arts was a responsibility of the state. Stuart Davis of the American Artists' Congress encapsulated the essence of this position when he advocated state arts subvention in the interest of preserving popular and democratic access to the arts:

Such conservation can continue only with the support of a government administration that will regard the arts, along with proper housing, playgrounds, health service, social security legislation, and educational facilities for all, as part of the basic obligations of a democratic government of all people towards the welfare of its citizens. (1973, p. 250)

Both the Artists' Union and the Congress trace their lineage to the John Reed Club. The John Reed Club was a radical cultural organisation established in 1929 in New York. ${ }^{9}$ At its meetings, lectures and art school the club taught that artist's interests were in harmony with those of the working classes and thus art should advance the position of the working classes. The American Artist's Congress was begun at a Reed Club meeting in 1935 , the same year the Reed Clubs were officially disbanded. Unlike the Reed Clubs the Congress was not specifically attached to the Communist Party, nevertheless, the Congress continued to be informed by the Reed Club's 'Prolecult' understanding of 'art as a social force'. ${ }^{10}$ However, for the Congress the artist was a cultural worker contributing towards the establishment of a popular democratic culture rather than the stimulation of a revolutionary working class.

\footnotetext{
${ }^{9}$ By 1933 the organisation had 200 members in New York (Monroe 1971, p. 34-36).

${ }^{10}$ The John Reed Club was a member of the International Union of Revolutionary Writers and thus received its policy directives direct from the Stalin regime (Harrison, p. 243).
} 
The Congress was established as part of the Popular Front policy of a united alliance against fascism. Like the Popular Front generally the Congress was supportive of New Deal programs and reforms. In the Congress we can observe an organisation dedicated to the opposition of fascism but at the same time advocating state support of the arts in the interests of popular democracy. The preamble to the first Artist's Congress, held in 1936, stated the reasons for its formation:

1. to unite artists of all aesthetic tendencies to enable them to attain their common cultural objectives;

2. to establish closer relationships between the artist and the people and extend the influence of art as a force of enlightenment;

3. to advocate and uphold permanent Governmental support for the advancement of American art;

4. to support other organised groups on issues of mutual interest in an effort to develop and maintain conditions favourable to art and human existence;

5. to oppose all reactionary attempts to curtail democratic rights and freedom of expression and all tendencies that lead to Fascism;

6. to oppose war and prevent the establishment of conditions that are conducive to the destruction of culture and detrimental to the progress of mankind. (in Baigell and Williams 1986 [1936], p. 11-12)

There are a number of interesting points in this statement of purpose, for our interests here I want to draw attention to the rhetorical connection made between state support for art and the preservation of democratic culture. For artists attached to the Congress there was no contradiction implied by the advocacy of state art programs on the one hand and the protection of a democratic culture against the threat of fascism on the other. In the papers of the first Artist's Congress, titled Artists Against War and Fascism, many of the papers make just this connection. For instance, A.R. Stavenitz argued that it 
'should be obvious that the prerequisite for a healthily progressing art in this country is a permanent, government-supported program, conceived and administered so as to make the efforts of our artists available to the public, to all the people' $(1936 / 86$, p. 180). In their introduction to the collection of essays from this first Congress Baigell and Williams argue that 'the disputes that might have arisen from such a contradiction between artists' desires for free expression and the government's political uses of official art were to a large extent circumvented by the nature of the Popular Front itself' (1986, p. 23). Tempting as it may be to tie together the cultural interests of the Popular Front and the New Deal and to find evidence of an, albeit short-lived, proletarian cultural sphere I argue instead that what is most characteristic of the Congress is a particular rationality for the governmentalisation of culture. This rationality while constructing the citizen as a freely participating member of a people's democracy manages the citizen and her freedom at arm's length.

In The Cultural Front Michael Denning argues that we can understand the relations between the cultural programs of the 1930s and the Popular Front as constituting a proletarian public sphere. This proletarian public sphere has had cultural effects beyond the 1930s according to Denning's conception of the 'laboring of American culture' (1998, p. xvi-xviii). Denning discusses the distinctive nature of the discursive conjunction of culture and the people across a range of institutional sites and in a range of cultural forms. He argues that the predominant cultural forms of the 1930s (including the New Deal art projects) are characteristic of the momentary dominance of a labor public sphere, a 'cultural front' which while not successful in establishing a hegemonic formation nevertheless 'reshaped American culture' (1998, p. xvi). This ambitious project is useful in its analysis of various characteristics of the 1930s cultural formation and its relation to left and labor institutions. 
There is not the space here to engage in an extensive analysis of Denning's arguments, for the purposes of this paper I want to limit myself to one main point in regards to Denning's analysis of the 1930s cultural front. ${ }^{11}$ As a result of Denning's theoretical framework the relations between culture and the various cultural institutional sites of the 1930s are understood as constituting a left counter hegemony. There are two main problems with this. First, due to Denning's use of 'left' and 'right' as defining categories of analysis he misses the important influence of the range of sites and discourses which can not be described as 'left'. For instance, the characteristically social democratic nature of 1930s cultural programs can be traced through the history of settlement houses and other philanthropic programs from the late nineteenth century. While Denning attends to a diverse range of institutional sites and cultural productions in his analysis he is limited by his attention to sites and productions which he (sometimes problematically) characterises as distinctively 'left'. This results in the impression that there was a strong left consensual 'flavour' across the various sites of his analysis which ranges from the cultural programs of the New Deal to the cultural apparatus of the cultural industries (see for instance Denning 1998, p. 39 and p. 44). This is to overstate the extent to which we can ascribe to a diverse range of sites and institutions a single political logic. This is not to deny the important influence of socialist ideas for the relations between culture and the people in the 1930s but it is to place limits on the extent to which we can define the 1930s conjunction between art and the people as essentially left.

\section{Conclusion}

The discussion of the FAP, the Community Art Centre Programme, the Section of Painting and Sculpture and the Artist's Congress has analysed the conjunction of art, citizenship and government across different state and non-state institutions and programs. Some of the shared characteristics of

${ }^{11}$ See for such analyses the symposium on The Popular Front in Labor History, 1998. 
these conjunctions have been noted, for instance, the advocacy of a participatory democracy via the focus on participatory cultural processes rather than specific cultural productions. At the same time I have also discussed these conjunctions in relation to the specific circumstances of their application and have noted that in each case the logics of their operation were negotiated and contradictory. In the case of the Negro Community Art Centres for instance, the discursive construction of these centres as a site for the reconnection of black communities as participating parts of a democratic and national whole was clearly fiction given the contemporaneous state of black disempowerment. Nevertheless, the participatory nature of both the funding of the centres and their administration meant that the communities of which they were a part directed the programs of the individual centres. For this reason the Director of the Harlem Community Art Centre, Gwendolyn Bennett, could claim that the centre was 'becoming not only a cultural force in its particular locale, but a symbol in the culture of a race' (1973, p. 213).

In relation to the Artist's Congress I discussed a particular conjunction of art, citizenship, and government which was characteristic of the 1930s more generally. On the one hand, I noted that the idea that subvention of culture was a state responsibility was predominant. This advocacy was often posed in terms of the notion that an educated and culturally aware populace would be less tempted by fascism. On the other hand, I drew attention to the equally predominant awareness of the need to guard against the kinds of 'government culture' which were characteristic of fascist countries. In this way then, the characteristic relationship between art, government, and citizenship in the 1930s was an 'arm's length' one, which in constructing the citizen as a free, participating member of a democracy acted upon this 'free' citizen in the very spaces of her or his freedom. 
One of the main functions of this paper has been to argue for a different set of terms for the analysis of the relations between culture and government. I have sought to unsettle accounts of the conjunction of culture and government which claim that this conjunction is characterised above all by relations of oppression or resistance, hegemony or counter-hegemony. Instead the analysis of art programs during the American Depression has presented some of the benefits of analysing cultural programs which takes account of the specificity of their concrete circumstances and operations. As already mentioned, this is far from denying the operation of particular and definite power effects, but rather to address those effects in relation to the specific conditions of their making.

We can draw lessons from the foregoing discussion of 1930s art programs for the analysis of contemporary governmental arrangements. In the introduction to this paper the contemporary culture/ government formation was characterised in terms of culture's 'privatisation'. In view of the argument of this paper that we must attend to conjunctions of culture and government in relation to their specificity I want to conclude with some remarks regarding the 'privatisation' of culture. Such a characterisation does not enable us to account for the ways in which state regulations still figure in important ways in culture's administration and distribution-in taxation provisions, in government cultural subvention at the state and council levels, and in Britain and Australia, for instance, at the central government level. It may be more useful to characterise the current culture/ government formation as being defined by a form of entrepreneurial governance characteristic of advanced liberal governmentality. Defining the culture/ government formation as one of a shift in forms of governance rather than primarily in forms of capital ownership allows us to recognise that the new forms of conduct characteristic of entrepreneurial governance are internal to state government programs as well as nonstate programs. At the same time it allows us to recognise that the introduction of entrepreneurial principles to those fields which, whether funded by public money or not, had previously been primarily 
defined by welfarist rationalities may undermine the basic principles of cultural democracy. Nikolas Rose encapsulates the essence of the shift well by describing it in this way, under the rationalities of welfare, social technologies were to civilise individuals, render them as citizens with obligations to conduct themselves with prudence in exchange for certain guarantees against uncertainty. In the new prudential regimes, individuals, educated through the mechanisms of marketing and the pedagogies of consumption and lifestyle, are to gain access to previously 'social' benefits such as educational advantage, health status and contentment in old age through purchase in a competitive market. (1996, p.

It is clear that we must scrutinise the predominance of this shift. However, while these advanced liberal 'death of the social' changes have been criticised particularly from the Left, the fact that they have been taken up in a variety of milieux indicates their diversity and potency. How are we then to scrutinise this shift usefully? Rose has asserted that if 'we are to gain a critical purchase upon these contemporary strategies for the conduct of conduct, it will be, in part through historical investigations which can unsettle and de-valorise the regime of subjectification to which they are inextricably linked' (1996b, p. 147). On this view analyses of the history of cultural formations which reject accounts based on one logic will give us a more productive purchase on contemporary cultural programs if we address conjunctions of art, citizenship and government in relation to the concrete conditions of their application and effect. 


\section{Bibliography}

Baigell, M. and Williams, J. 1986 [1936], Artists Against War and Fascism: Papers of the First American Artists' Congress, Rutgers University Press, New Brunswick.

Beckham, S.B. 1989, Depression Post Office Murals and Southern Culture: A Gentle Reconstruction, Louisiana State University Press, Baton Rouge.

Bennett, Gwendolyn 1973, 'The Harlem Community Art Centre', in O'Connor F.V., ed., Art for the Millions: Essays from the 1930s by artists and Administrators of the WPA Federal Art Project, New York Graphic Society, Boston.

Berman, G. 1975, The Lost Years: Mural Painting in New York City under the Works Progress Administration's Federal Art Project, 1935- 1943, unpublished dissertation Columbia University.

Burroughs, M.G. 1987, 'Chicago’s South Side Community Art Centre: A Personal Recollection', White, J.F., ed., Art in Action: American Art Centres and the New Deal, The Scarecrow Press, London.

Crow, T.E. 1985, Painters and Public Life in Eighteenth-Century Paris, London, Yale University Press.

Davis, Stuart 1973, 'American Artists' Congress' in O’Connor, F.V., ed., Art for the Millions: Essays from the 1930s by Artists and Administrators of the WPA Federal Art Project, New York Graphic Society, Boston. 
Denning, M. 1998, The Cultural Front: The Laboring of American Culture in the Twentieth Century, Verso, London.

Foucault, M. 1991, 'Governmentality', in The Foucault Effect, Burchell, G. et al, eds., Harvester Press, London.

Gibson, L. 1999, 'The Arts as Industry', Media International Australia incorporating Culture and Policy, 90, 107-122.

Harris, Jonathan 1995, Federal Art and National Culture: The Politics of Identity in New Deal America, Cambridge University Press, Cambridge, Massachusetts.

Harrison, H.A., 'John Reed Club Artists and the New Deal: Radical Responses to Roosevelt's “Peaceful Revolution", Prospects, 5, 241- 268.

Labor History, 1998, 39, 3.

Marantz, Irving. J. 1973, 'The Artist as Social Worker' in O'Connor, F.V., ed., Art for the Millions: Essays from the 1930s by Artists and Administrators of the WPA Federal Art Project, New York Graphic Society, Boston.

Marling, K.A. 1982, Wall to Wall America: A Cultural History of Post-Office Murals in the Great Depression, University of Minnesota Press, Minneapolis. 
McDonald, W.F. 1969, Federal Relief Administration and the Arts, Ohio State University Press, Ohio.

McKinzie, R.D. 1973, The New Deal for Artists, Princeton University Press, New Jersey.

Monroe, G.M. 1971, The Artists Union of New York, Ph.D. Dissertation, New York University.

O’Connor, F.V. 1969, Federal Support for the Visual Arts: The New Deal and Now, New York Graphic Society Ltd., Boston.

Park, M. and Markowitz, G.E. 1992, 'New Deal for Public Art', in Senie, H.F. and Webster, S., eds., Critical Issues in Public Art: Content, Context, and Controversy, Harper Collins, New York.

Park, M. and Markowitz, G.E. 1984, Democratic Vista: Post Offices and Public Art in the New Deal, Temple University Press, Philadelphia.

Rose, N. 1996, 'Identity, Genealogy, History', du Gay, P., ed., Questions of Cultural Identity, Sage, London.

Rose, N. 1996b, 'The death of the social? Re-figuring the territory of government', Economy and Society, 25, 3, 327-356.

Rosenburg, H. 1975, Art on the Edge: Creators and Situations, The University of Chicago Press, Chicago. 
Smith, P. 1987, Redeeming the Time: A People's History of the 1920s and the New Deal, McGraw-Hill Book Company, New York.

Stavenitz, A.R. 1986 [1936], 'Economic Status of the Artist Today' in Baigell, M. and Williams, J., eds., Artists Against War and Fascism: Papers of the First American Artists' Congress, Rutgers University Press, New Brunswick.

Sutton, Harry 1973, 'High Noon in Art' in O'Connor F.V., ed., Art for the Millions: Essays from the 1930s by Artists and Administrators of the WPA Federal Art Project, New York Graphic Society, Boston.

White, J.F. 1987, 'Introduction', White J.F., ed., Art in Action: American Art Centres and the New Deal, The Scarecrow Press, London. 